\title{
Settlements Growth and Development in Semarang City Centre Area, Indonesia
}

\author{
Bitta PIGAWATI ${ }^{*}$, Nany YULIASTUTI' ${ }^{1}$, Fadjar Hari MARDIANSJAH ${ }^{1}$ \\ ${ }^{*}$ Corresponding author \\ ${ }^{1}$ University of Diponegoro, Faculty of Engineering, Department of Urban and Regional Planning, Semarang, INDONESIA \\ E-mail: pigawati@gmail.com, nanyuliastuti@gmail.com,fadjar_mardiansjah@yahoo.com \\ DOI: 10.24193/JSSP.2019.2.03 \\ https://doi.org/10.24193/JSSP.2019.2.03
}

K e y w o r d s: residential development, residential growth, metropolitan area, city centre, built-up area, land-use

\begin{abstract}
A B S T RACT
Semarang is among the important metropolitan regions of Indonesia, and it is affected by the growth and development of the composing residential areas, especially in the central area. The main focus of this research is to analyse and understand the current problems, including aspects of land use, residential patterns, residential development directions, and characteristics of the communities in residential growth areas. We used Quick Bird image data as the primary data source, and maps and statistical data as the secondary. Descriptive statistics and spatial analysis were used in analysing the data. Semarang city centre area consisting of six districts that were selected as study area. Results indicate that there has been a 2.08\% expansion of residential areas during a decade, from 2006 to 2016. Population in the expansion areas increased by $4.33 \%$, while the majority of the population has average education level. They mostly work in manufacturing industries, construction, and various trade and services facilities. There are three residential patterns identified in the study area, i.e., clustered, random and dispersed. Although much land suitable for residential use is still available in the study area we learned that growth of residential areas occurs also in areas with land unsuitable for this particular use, such as preserved and disaster-prone areas. These findings can help planners to reformulate policies and strategies for future residential development.
\end{abstract}

\section{INTRODUCTION}

Urban growth is a complex and dynamic process involving changes in the physical and functional components of the built environment (Sahana, Hong, and Sajjad, 2018), in which residential growth and development are essential. Residential is generally called as settlement and it is specifically referred to as a house (Hammond C W, 1979; Hudson, 1974). The main factor affecting the physical expansion of a city is the population growth rate and land consumption per capita (Bagheri and Tousi, 2017). Urban expansion characteristics are often locally specific, based on determinants such as economic, social, demographic, and planning (Xu and Zhang, 2017; You and Yang, 2017). Urban expansion rate is generally twice higher than population growth rate (Seto, Fragkias, Güneralp, and Reilly, 2011) and one of the triggered problems is the tendency of over-concentration in certain areas causing imbalance or uneven distribution of service centres. Meanwhile, access to opportunities and employment is often the top reason for people in choosing a residential location (Christiaensen and Todo, 2013; Rodríguez-Pose and Hardy, 2015; Satterthwaite, 2006). It makes the city centre or downtown area most favourable because the large-scale modern activities, social infrastructure and decisionmaking centres are entirely available in the area (Donaghy, 2013).

Urban growth also implies changes in land use or land cover (Patino and Duque, 2013). In this paper, the built-up area is broadly defined as having 
residential, commercial and industrial uses. Therefore, the growth direction of a city can be tracked based on the direction of the residential growth. It is often found that conservation areas and green open spaces such as city parks are transformed into built-up areas. Fast and irregular city expansion driven by the high rate of economic growth has been criticised as being the primary cause of green land loss, social inequality and urban environmental damage in China (Cheng and Masser, 2003; Ding, 2009; Wang, Krstikj, and Koura, 2017; Yeh, 1999). In Semarang, urbanisation and urban sprawl cause changes in land use (Aprillia and Pigawati, 2018). Thus it becomes essential for land managers and decision-making authorities to monitor urban growth (Patino and Duque, 2013).

Many current urban problems in Indonesia have the origin in the high population growth rate, the increasing housing need being the main issue. Weak law enforcement and low public awareness of the spatial plan result in the improper use of space. The development of urban residential areas is usually controlled through policy instruments such as master (spatial) plans, development plans and zoning regulations. Policies are designed to manage urban development, aiming to create cities able to meet the people needs (McGill, 1998; Porter, 2012; Richardson, 1993; Werna, 1998). Residential areas around the world may change spatially; yet, the patterns of spatial change might vary as along with their driving factors (Mahavir, 1996; Sarkar, 2010).

Residential growth is significantly affected by the accessibility to the city centre with its complete infrastructure and facilities (Bitta Pigawati, Yuliastuti, and Mardiansjah, 2017). It may have caused many residential areas in Semarang suburbs to occupy pieces of unsuitable land, e.g. the disaster-prone land. Housing providers in developing countries usually agree that residential areas are provided for low-income society (Keivani and Werna, 2001). This is not a good practice, and against best practices. The 1999 guideline on housing density in Ireland, for example, recommends planning authorities that an increase in housing density in large cities (with the population of 5,000 people or more) should be directed to establish a sustainable residential pattern in a suitable location (Government of Ireland, 2009). Meanwhile, Sweden has implemented urban planning reforms related to time-efficiency policies to build housing areas as a basis for reducing housing shortages in growth areas (Granath Hansson, 2017). In the United States, there are concerns about the construction of low-density housing because it is built in an unsuitable location in rural areas, which have a lot of natural resources (Mockrin, Reed, Pejchar and Jessica, 2017).

The attractiveness of Semarang City as the centre of its metropolitan region has led to the rapid growth and physical development of the city centre area. This area, which was originally a residential area, has developed into various uses such as offices, commercial uses, and communication centers. Semarang city centre area has high population density and witnesses rapid demographic changes. The highest concentration of population density in Semarang is on the radius of four kilometres from the city centre and decreases significantly towards the periphery (Handayani and Rudiarto, 2014). The population of Semarang City reached $1,729,428$ people in 2016 distributed in an area of $373.7 \mathrm{~km}^{2}$. Therefore, the population density of Semarang is of 4,628 people/ha (Central Bureau of Statistics, 2018).

Along with the development of Semarang City as a metropolitan centre, the residential districts in the city centre area grow rapidly and spread to all directions. This phenomenon may threaten the sustainability of development, as some studies concerning the broader spatial dynamics have indicated (Buchori and Sugiri, 2016; Buchori et al., 2015; Buchori et al., 2017). Hence, the question is "what patterns and characteristics are there in the rapid growth and development of residential areas in Semarang city centre area?" The main objective of this research is, therefore, to analyse and comprehend the residential growth and development in Semarang City Centre Area focusing on residential patterns, development directions, and characteristics of residents in the residential expansion area on a period of 10 years (2006-2016). The research has used the quantitative descriptive method and spatial analysis using the Geographic Information System and Remote Sensing technology.

\section{STUDY AREA}

The area selected for study is the city centre area of Semarang, consisting of six districts (kecamatan), namely the districts of Candisari, Gajahmungkur, Gayamsari, Semarang Selatan (South Semarang), Semarang Tengah (Central Semarang) and Semarang Timur (East Semarang), which are shown in Figure 1.

The area covers $41.56 \mathrm{~km}^{2}$, and recorded decline in the number of population from 453,426 people in 2006 to 420,220 inhabitants in 2016 (Central Bureau of Statistics, 2018). Land morphology shows mostly flat and hilly areas. Four districts located in the north, namely, Semarang Tengah, Semarang Timur, Gayamsari, and Semarang Selatan overlap flat lands, while the land where the other two districts are located is hilly with gentle to steep slopes. The study area includes at least three disaster-prone sectors. Floodprone areas are found in Semarang Tengah, Semarang Selatan, and Gayamsari, while land subsidence-prone areas are found in Semarang Tengah, Gayamsari, and Semarang Timur; another landslide-prone area is in 
Gajahmungkur (Government of the City of Semarang, 2011).

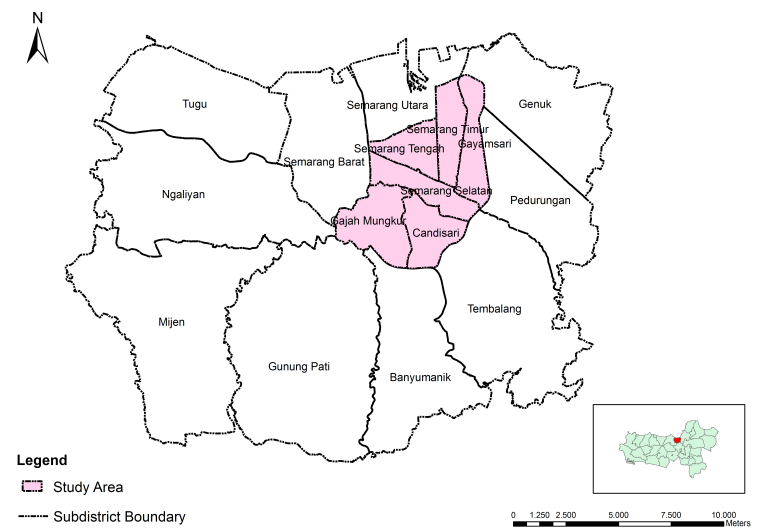

Fig.1. The study area. Semarang city centre area.

\section{THEORY AND METHODOLOGY}

\subsection{Theoretical framework}

It is essential to discuss some views in defining the city to understand city growth and development. A city is a relatively large, dense and permanent residential area inhabited by people with various social positions, whose livelihood is dominantly nonagricultural (Daldjoeni, 1987). Urban development occurs in metropolitan areas throughout the world, especially in developing countries (Lal, Kumar, and Kumar, 2017).

City development implies physical change as a result of urban development. City development is determined by various factors, eventually improving the level of productivity and the quality of life (Glaeser, Kallal, Scheinkman, and Shleifer, 1992). The concentric zone theory, proposed initially by Burgess, McKenzie, and Wirth (1925), is a model of urban development that proliferates itself from its original centre expanding outwards. Meanwhile, multiple nuclei model deals with urban spatial development based on the central growth theory proposed initially by Harris and Ullman (1945). City growth starts from a centre to become a complex form caused by the appearance of new nuclei with the function of growth centres.

The city centre area is defined as a saturated zone in which residential growth has reached the maximum level (Cats, Zhang, and Nissan, 2016; Chadwick and Collins, 2015). City centre is the core of a city that has been growing from a residential into central business district (Bourne, 1982), which functions as a centre of economic activities, housing facilities and relatively complete types of infrastructure (Ferreira and Condessa, 2012; Simich et al., 2005). Its central location has high accessibility as a result of rapid development. An essential indicator of city development is the increase of the built-up land for residential purposes. Furthermore, in other cases, for instance the housing system in Nigeria, the reasons for housing shortages in Nigeria include poverty, high level of urbanisation, high prices of building materials, and imperfect building technology (Festus et al., 2015). Many of the Semarang suburbs are inhabited by industrial workers who have low income and education level.

Any residential area has a dynamic structure that can grow and develop at any time. Residential areas can develop according to a multi-directional pattern, and therefore can be distributed linearly while others clustered in several places (Olajoke, 2017). The formation of residential areas is a functional process based on patterns of human activities, physical and non-physical aspects that directly affect these activities and land utilisation (Rapoport, 1969). It caused by several factors, both physical and non-physical, that can be locally specific. The spatial pattern of residential areas is a continuous dependency relationship between the physical and human elements (Wulangsari, 2014). Relationships between elements in the physical environment create a space in which humans are interconnected and perform activities so that a residential pattern may represent the physical characteristics of the housing area and the socio-economic conditions of residents (Hudson, 1974; Whynne-Hammond, 1985).

The residential pattern gives an impression on housing distribution and density (Zee, 1979). Complex facilities and infrastructure in an area act as an attraction factor for people when choosing a location to live. Factors affecting this selection are accessibility, space and land availability, availability of residential facilities and infrastructure, and basic physical and environmental conditions (Budihardjo, 1991). In terms of factors influencing residential growth we mention the natural physical, social, and geographic factors (Sumaatmadja, 1989; Yang, Xu, and Long, 2016), physical characteristics of residential environment, availability of facilities and services, social environment, ethnic and demographic factors, and housing characteristics (Golledge and Stimson, 1987). Accordingly, factors that affect residential patterns vary and usually include the distribution of infrastructure and social facilities for transportation and socioeconomic activities of steepness areas and the size of national population, economic factors, per capita income and topographic conditions (Ahmed, 2009; Clarke, 1985; Maza, Villaverde, and Hierro, 2013; Oruç, 2013; Whynne-Hammond, 1985).

The residential pattern is a reflection of population adjustment to the environment, the level of which is highly dependent on the socio-economic and cultural factors of the population. Social status is one of the driving factors for residential clustering (Pacione, 1984). It is generally caused by social class and the availability of land to build residential dwellings. People tend to choose residential locations based on 
environmental characteristics such as location, education, crime rate, environmental quality, sociodemographic composition facilities, residential characteristics and land prices (Pigawati, Yuliastuti, and Mardiansjah, 2018). The residential pattern can be determined based on the model and analysis of the nearest neighbourhood analysis, that is, by using the nearest neighbour parameter (T) (Hagget, 1985).

Remote sensing refers to the activities of recording, observing, and perceiving (sensing) objects or events in far-away (remote) places (Weng, 2010). This technique can provide information on changes in magnitude, direction, and land use pattern (Marble, Dadhich, and Hanaoka, 2012). There have been many approaches to map urban areas with remote sensing satellite imagery and monitor changes in land cover from a local to a global scale (Akintunde, Adzandeh, and Fabiyi, 2016). The technique is useful for mapping and monitoring the natural and human-made features. Remote sensing technique strongly supports urban studies (Bhatt, Gupta, and Gogoi, 2006), and together with GIS, it can also be used to map and analyse the residential distribution (Pigawati and Rudiarto, 2011).

\subsection{Methods}

Both primary and secondary data were used in this research. The primary data sources are QuickBird images of the study area in 2006 and 2016. The secondary data sources include official maps and population data of the study area. Descriptive statistics and geospatial techniques were used to analyse data collected. The steps of the analysis were as follows: a). Analysis of land use in the study area for ten-year period (2006-2016), conducted through QuickBird imagery interpretation and overlay technique; b). Analysis of residential growth and development through QuickBird imagery interpretation and overlay technique; c). Analysis of residential patterns and the expansion directions using ArcGIS software, nearest neighbourhood and spatial analysis techniques; d). Analysis of factors affecting the residential growth and development using descriptive statistics; e). Analysis of the characteristics of the residential expansion in the study area.

\section{RESULTS AND DISCUSSION}

\subsection{Land use in the city centre}

The built-up area in 2006 was of 30,992,481 $\mathrm{m}^{2} \quad(74.57 \%$ of the total area). After 10 years, it increased to $31,540,675 \mathrm{~m}^{2}(75.89 \%)$. The largest percentage of land use in Semarang city centre area is for residential purposes, i.e. $23,806,224 \mathrm{~m}^{2}(57.28 \%)$ in 2006 and $24,300,299 \mathrm{~m}^{2}(58.47 \%)$ in 2016 , or an increase of 494,075 $\mathrm{m}^{2}$ of residential use.
Land conversion was noticed in some locations, namely in Candisari District, where land used for trade and services was turned into residential area.

Table 1 shows land use changes in the study area during the ten years while Figure 2 shows the changes in the spatial distribution in 2006 compared to 2016.

Table 1. Land use change in Semarang city centre area of $2006-2016$.

\begin{tabular}{|c|c|c|c|}
\hline \multirow{2}{*}{ District } & \multicolumn{3}{|c|}{ Non Built Up Area $\left(\mathbf{m}^{2}\right)$} \\
\hline & 2006 & 2016 & $\Delta$ \\
\hline Candisari & 1.225 .683 & 1.058 .180 & -167.503 \\
\hline Gajahmungkur & 3.888 .411 & 3.655 .396 & -233.015 \\
\hline Gayamsari & 2.841 .120 & 2.784 .273 & -56.847 \\
\hline Semarang Selatan & 408.594 & 408.587 & -7 \\
\hline SemarangTengah & 157.437 & 80.855 & -76.582 \\
\hline Semarang Timur & 2.048 .279 & 2.034 .049 & -14.230 \\
\hline Total & 10.569 .525 & 10.021 .341 & -548.183 \\
\hline$\%$ x Total area & 25,43 & 24,11 & $-1,32$ \\
\hline \multirow{2}{*}{ District } & \multicolumn{3}{|c|}{$\begin{array}{l}\text { Built Up Area }\left(\mathbf{m}^{2}\right) \\
\text { Industry }\end{array}$} \\
\hline & 2006 & 2016 & $\Delta$ \\
\hline Candisari & 0 & 0 & 0 \\
\hline Gajahmungkur & 3.555 & 4.938 & 1.383 \\
\hline Gayamsari & 83.370 & 88.008 & 4.639 \\
\hline Semarang Selatan & 17.974 & 17.974 & 0 \\
\hline SemarangTengah & 13.561 & 13.561 & 0 \\
\hline Semarang Timur & 318.448 & 318.448 & 0 \\
\hline Total & 436.908 & 442.930 & 6.021 \\
\hline$\% \times$ Total area & 1,05 & 1,07 & 0,01 \\
\hline \multirow[t]{2}{*}{ District } & \multicolumn{3}{|c|}{$\begin{array}{l}\text { Built Up Area }\left(\mathrm{m}^{2}\right) \\
\text { Trade and Services }\end{array}$} \\
\hline & 2006 & 2016 & $\Delta$ \\
\hline Candisari & 411.299 & 400.284 & -11.016 \\
\hline Gajahmungkur & 194.700 & 172.439 & -22.261 \\
\hline Gayamsari & 362.987 & 387.054 & 24.067 \\
\hline Semarang Selatan & 1.557 .032 & 1.557 .039 & 7 \\
\hline SemarangTengah & 3.407 .471 & 3.464 .761 & 57.289 \\
\hline Semarang Timur & 813.855 & 813.855 & 0 \\
\hline Total & 6.747 .343 & 6.795 .430 & 48.087 \\
\hline$\%$ x Total area & 16,24 & 16,35 & 0,12 \\
\hline \multirow[t]{2}{*}{ District } & \multicolumn{3}{|c|}{$\begin{array}{c}\text { Built Up Area }\left(\mathbf{m}^{2}\right) \\
\text { Residential }\end{array}$} \\
\hline & 2006 & 2016 & $\Delta$ \\
\hline Candisari & 4.903 .018 & 5.081 .536 & 178.518 \\
\hline Gajahmungkur & 4.983 .334 & 5.237 .227 & 253.894 \\
\hline Gayamsari & 2.892 .524 & 2.920 .664 & 28.140 \\
\hline
\end{tabular}




\begin{tabular}{|c|c|c|c|}
\hline Semarang Selatan & 3.946 .400 & 3.946 .400 & 0 \\
\hline SemarangTengah & 2.561 .531 & 2.580 .823 & 19.292 \\
\hline Semarang Timur & 4.519 .418 & 4.533 .648 & 14.230 \\
\hline Total & 23.806 .224 & 24.300 .299 & 494.075 \\
\hline$\% \times$ Total area & 57,28 & 58,47 & 1,19 \\
\hline \multirow{2}{*}{ District } & \multicolumn{3}{|c|}{$\begin{array}{c}\text { Built Up Area }\left(\mathrm{m}^{2}\right) \\
\text { Total }\end{array}$} \\
\hline & 2006 & 2016 & $\Delta$ \\
\hline Candisari & 5.314 .317 & 5.481 .820 & 167.503 \\
\hline Gajahmungkur & 5.181 .589 & 5.414 .604 & 233.015 \\
\hline Gayamsari & 3.338 .880 & 3.395 .727 & 56.847 \\
\hline Semarang Selatan & 5.521 .406 & 5.521 .413 & 7 \\
\hline SemarangTengah & 5.982 .563 & 6.059 .145 & 76.582 \\
\hline Semarang Timur & 5.651 .721 & 5.665 .951 & 14.230 \\
\hline Total & 30.992 .481 & 31.540 .675 & 548.183 \\
\hline$\% \times$ Total area & 74,57 & 75,89 & 1,32 \\
\hline District & \multicolumn{3}{|c|}{$\begin{array}{c}\text { Total Area } \\
\left(\mathbf{m}^{2}\right)\end{array}$} \\
\hline Candisari & & & 6.540 .000 \\
\hline Gajahmungkur & & & 9.070 .000 \\
\hline Gayamsari & & & 6.180 .000 \\
\hline Semarang Selatan & & & 5.930 .000 \\
\hline SemarangTengah & & & 6.140 .000 \\
\hline Semarang Timur & & & 7.700 .000 \\
\hline Total & & & 41.560 .000 \\
\hline$\% \times$ Total area & & & 100,00 \\
\hline
\end{tabular}

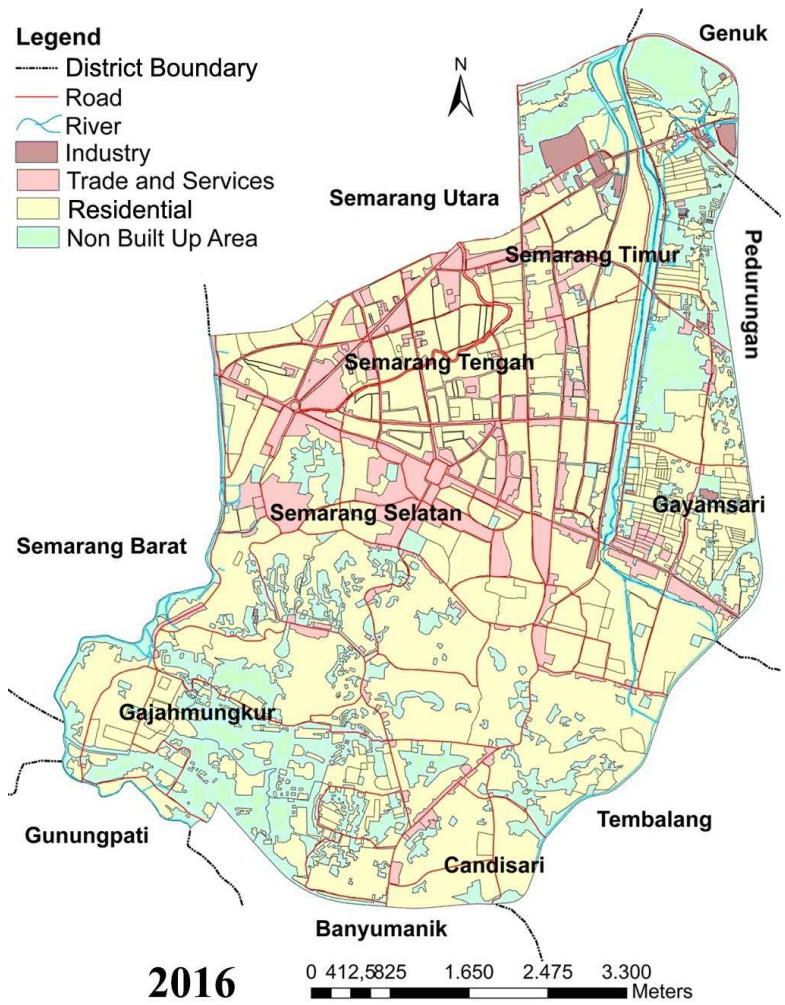

Fig. 2. Land use in Semarang city centre area in 2006 and 2016.

\subsection{Growth and development of residential areas in the period 2006-2016}

Gajah Mungkur and Candisari Districts have fairly larger residential areas compared to the other districts. These districts have a large type of housing with open spaces built since quite a long time ago. On the other hand, residential development in Semarang Selatan District has been vertical due most probably to its location that is close enough to the Central Business District (CBD). Most of the land in Semarang Selatan is used for trade and service activities while the remaining is designated to green open spaces. Land price in this district is therefore quite high. Table 2 shows the growth and development of residential areas in the period 2006-2016.

Table 2. Growth and development of residential areas in the analysed area 2006-2016.

\begin{tabular}{|l|r|r|r|}
\hline \multirow{2}{*}{\multicolumn{1}{|c|}{ District }} & \multicolumn{3}{c|}{ Residential area $\left(\mathbf{m}^{\mathbf{2}}\right)$} \\
\cline { 2 - 4 } & $\mathbf{2 0 0 6}$ & $\mathbf{2 0 1 6}$ & \multicolumn{1}{c|}{$\Delta$} \\
\hline Candisari & $4,903,018$ & $5,081,536$ & 178,518 \\
\hline Gajahmungkur & $4,983,334$ & $5,237,227$ & 253,894 \\
\hline Gayamsari & $2,892,524$ & $2,920,664$ & 28,140 \\
\hline Semarang Selatan & $3,946,400$ & $3,946,400$ & 0 \\
\hline Semarang Tengah & $2,561,531$ & $2,580,823$ & 19,292 \\
\hline Semarang Timur & $4,519,418$ & $4,533,648$ & 14,230 \\
\hline Total & $23,806,224$ & $24,300,299$ & 494,075 \\
\hline
\end{tabular}


The expansion of housing areas in the study area occurred in five districts, spreading over twentyone villages. The largest residential expansion in Gajahmungkur District is of $253,894 \mathrm{~m}^{2}$. Figure 3 shows the spatial distribution of the residential development in the period 2006-2016.

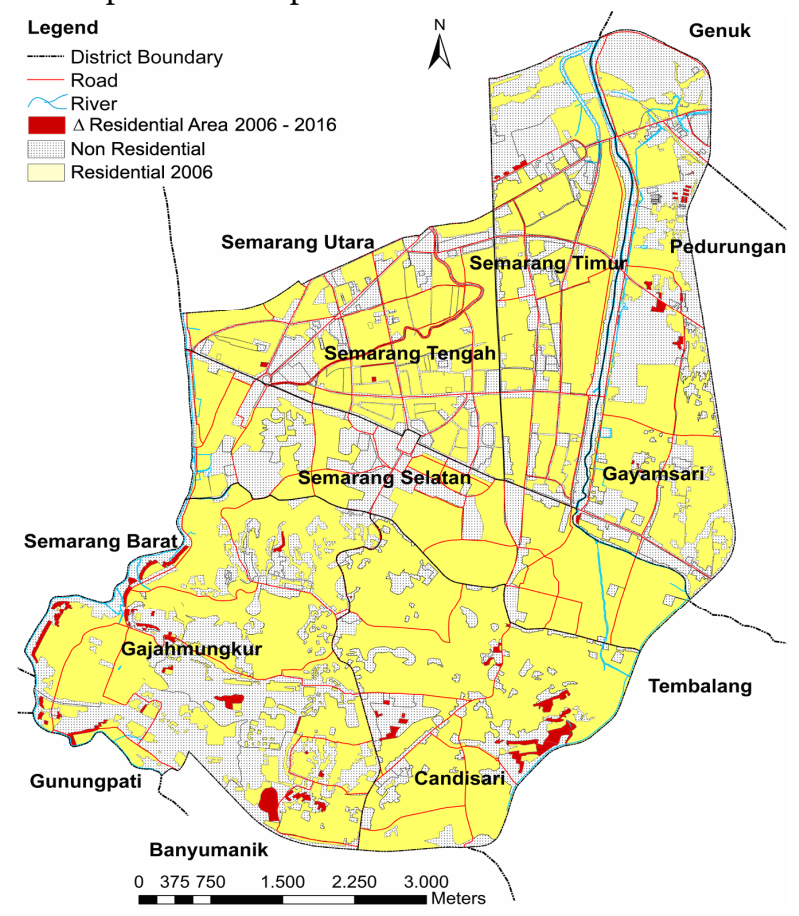

Fig. 3. Expansion of residential areas 2006-2016.

\subsection{Residential patterns}

Residential patterns show the nature of residential distribution resulting from the relationships between factors determining the nature of the distribution.

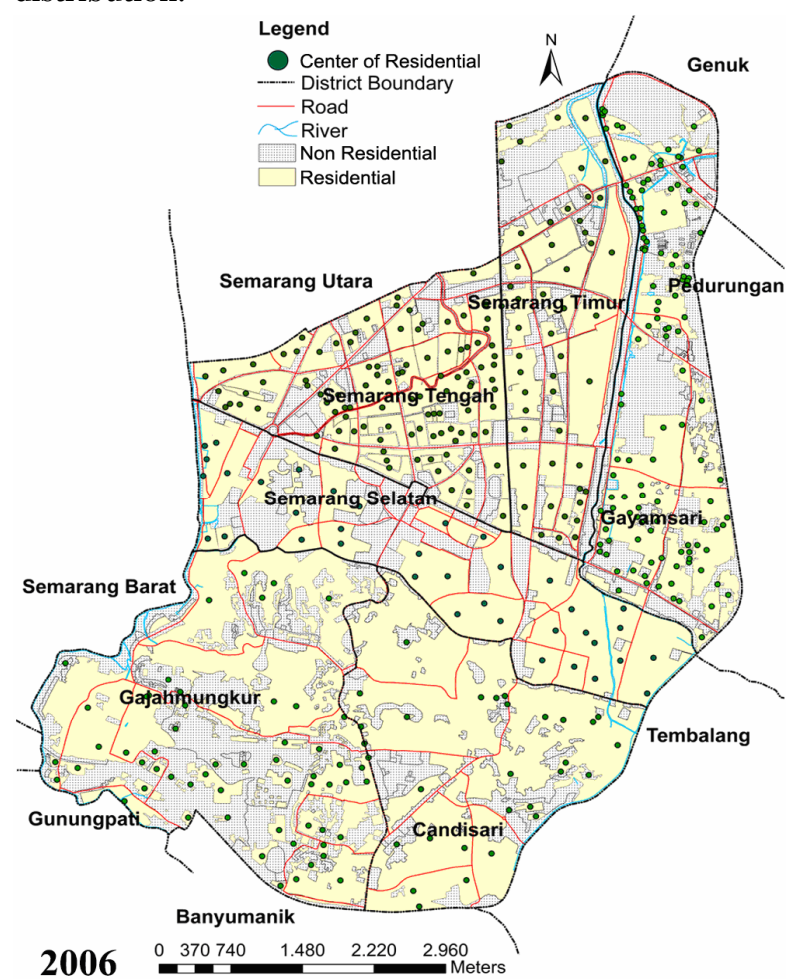

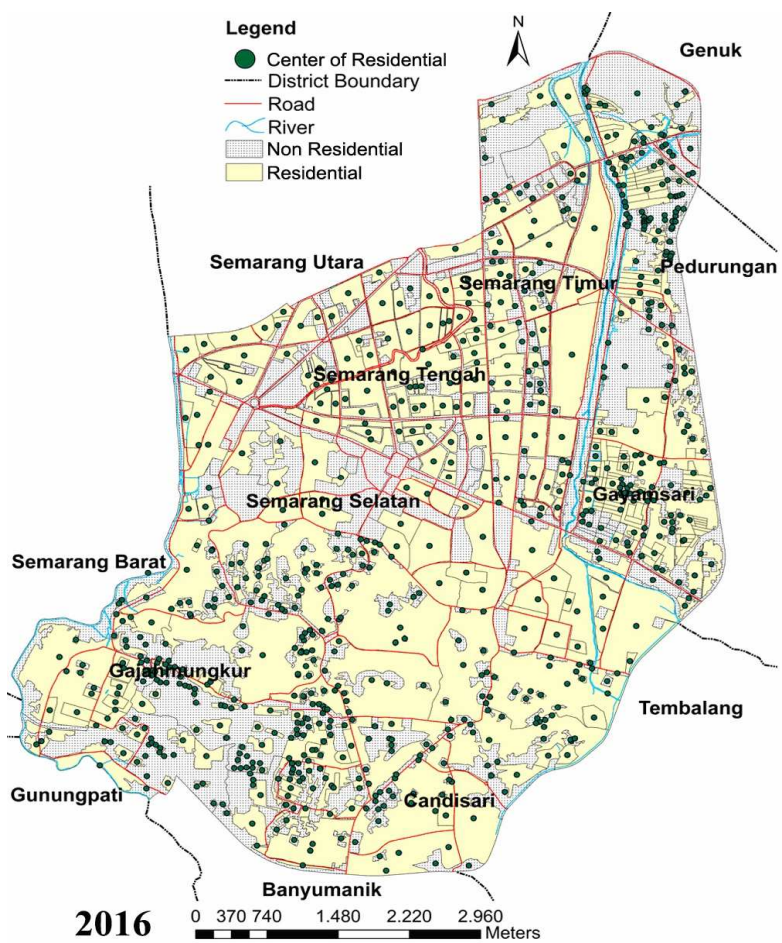

Fig. 4. Distribution of centre points in residential areas, in 2006 and 2016

Figure 4 shows the distribution of residential areas' centre points in 2006 and 2016.

The nearest neighbourhood analysis was employed to determine the patterns by using ArcGIS software (the spatial function of Statistics Tools, Average Nearest Neighbourhood). Figure 5 shows the results of the statistical analysis of the spatial patterns.

The residential patterns found in the study area are clustered, random, and dispersed. Social classes and access to facilities generally cause residential clustering. People choose their residential areas based on characteristics such as location, education, crime rate, environmental quality, sociodemographic composition facilities, residential characteristics and land prices (Pigawati et al., 2018). Meanwhile, random residential pattern is an indication of homogeneous physical space related to the social composition (Sarkar, 2010), and dispersed pattern provides an impression of physical distribution that is related to the density of the residents (Zee, 1979).

Table 3. Residential patterns in 2006 and 2016.

\begin{tabular}{|l|l|l|}
\hline \multirow{2}{*}{\multicolumn{1}{|c|}{ District }} & \multicolumn{2}{c|}{ Residential pattern } \\
\cline { 2 - 3 } & \multicolumn{1}{c|}{$\mathbf{2 0 0 6}$} & \multicolumn{1}{c|}{$\mathbf{2 0 1 6}$} \\
\hline Candisari & Random & Random \\
\hline Gajahmungkur & Random & Random \\
\hline Gayamsari & Clustered & Random \\
\hline Semarang Selatan & Random & Dispersed \\
\hline Semarang Tengah & Clustered & Dispersed \\
\hline Semarang Timur & Dispersed & Dispersed \\
\hline
\end{tabular}




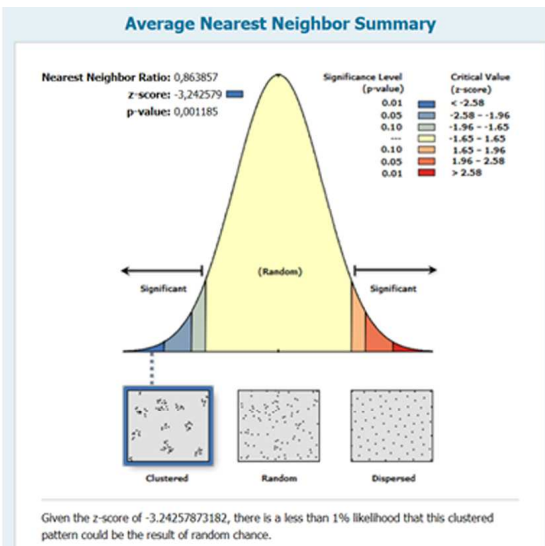

Clustered

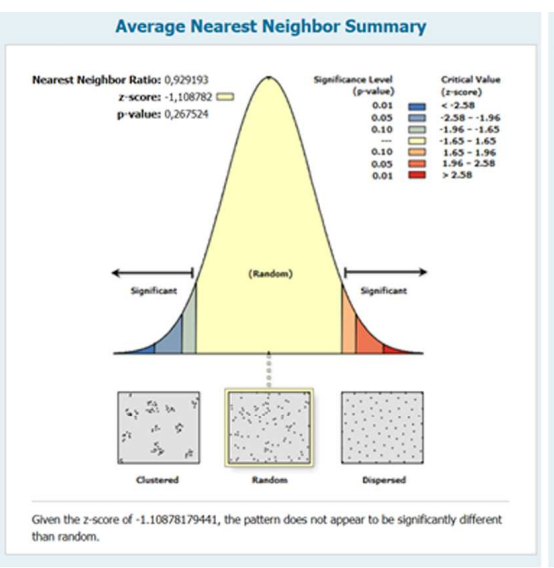

Random

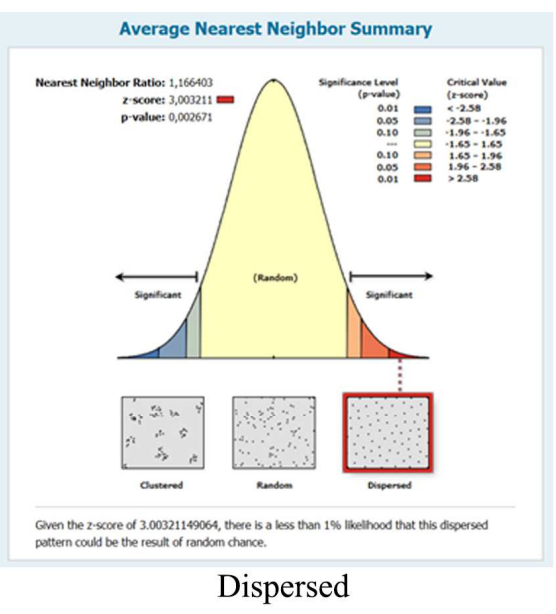

Fig. 5. Spatial statistics of residential patterns.

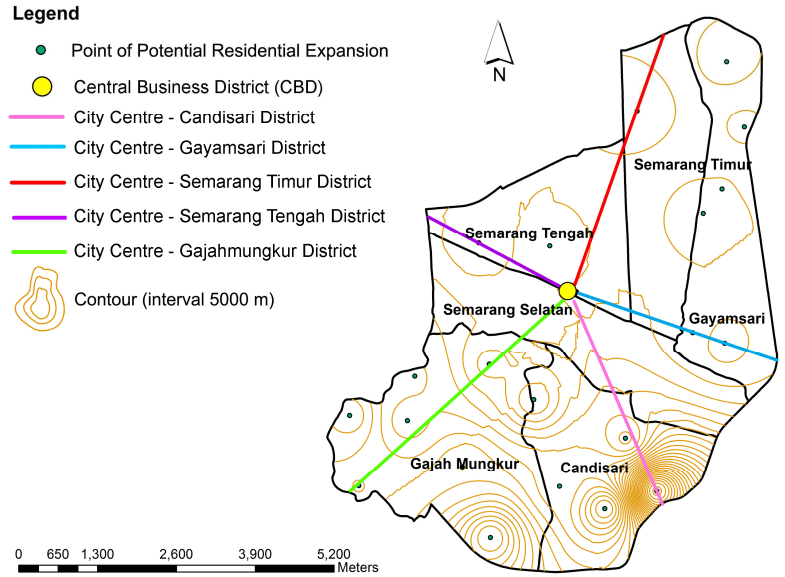

Fig. 6. The contour of potential expansion of residential areas in the period 2006-2016.

Also, dispersed residential pattern is frequently found in residential areas with steep topography. Table 3 shows changes in residential patterns in 2006 and 2016. Figure 6 indicates the potential contour of residential expansion in the period of 2006-2016, displaying a contour image of expansion potential scattered across the study area.

Meanwhile, Figure 7 shows the graphs of relationships between the expansion of the residential area and the distance to the CBD. This figure represents the development pattern of residential areas which is significant to the distance from the CBD. In Gajah Mungkur and Candisari districts, the same pattern was observed, that the housing areas have expanded farther from the CBD. On the other hand, the expansion direction in Gayamsari and Semarang Tengah Districts was towards the CBD.
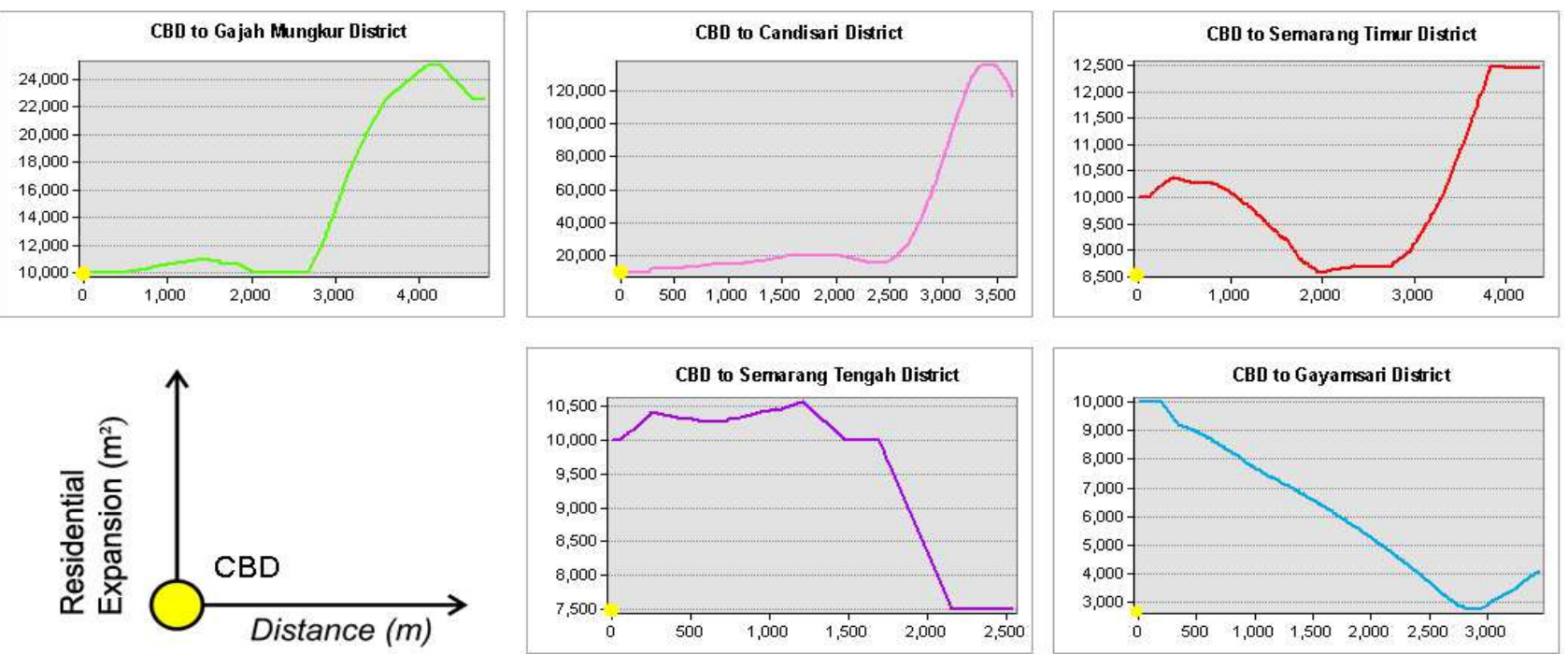

Fig. 7. Graphs of residential expansion and distance from CBD.

\subsection{Residential development factors}

The analysis of factors affecting the development of residential areas was performed by using statistical techniques. Correlation analysis was used to find the relationship between two variables. The relationship of the two variables can occur due to a causal relationship or by mere chance. Two variables 
are said to correlate if changes in one variable will be followed by those in the other one regularly, whether in the same direction (positive) or in the opposite one (negative).

Results show that there is a significant relationship between the expansion of residential areas and several other research variables. The correlation coefficients (C) confirm the influence of these variables on the expansion of residential areas in the period 2006-2016. The most influencing is infrastructure availability with a correlation coefficient of 0.88 , followed by accessibility ( $\mathrm{C}=0.59$ ), education $(\mathrm{C}=$ 0.57), and travel time to city centre/CBD $(\mathrm{C}=-0.47)$. Meanwhile, distance from $\mathrm{CBD}(\mathrm{C}=0.03)$ has not significantly influenced the residential expansion in the study area.

Planning for future development of residential areas in this area should, therefore, take these factors into account.

\subsection{Characteristics of residential areas expansion}

Population in the residential expansion areas has increased by $4.33 \%$ from 2006 to 2016.

The analysis shows that the majority of the population work as industrial and construction labourers (47.02\%) and engage in trade and service activities (17.06 \%). The education level of almost all of them (90.86\%) is high school or below.

Residential areas in the analysed area that is supposed to be a conservation area is of $146,310 \mathrm{~m}^{2}$ (29.61\% of the total residential expansion area). Also, as much as $87,643 \mathrm{~m}^{2}(17.73 \%$ of the total residential expansion area) of flood prone area is used for housing. Two other unsuitable areas used for housing are the subsidence-prone area of $68,839 \mathrm{~m}^{2}(13.93 \%)$ and landslide-prone area of $188,442 \mathrm{~m}^{2}$ (38\%). A bit fortunate, perhaps, is that the image data shows the potential for disasters in the study area as minor.

\section{CONCLUSIONS}

The patterns of residential growth and development in Semarang city centre area show the internal restructuring process mainly characterised by filling in or converting the non-built-up land. However, residential areas also occupy land, which was previously used for trade and service activities, especially in the form of changed function from shopping complex buildings to Rukos (Rumah Toko, literally means House Store), mixed use of residential and trade or service activities.

The dominantly horizontal residential expansion has occurred in Gajah Mungkur and Candisari Districts. Unfortunately, housing has also expanded to unsuitable plots of land, namely conservation and disaster-prone areas. The two districts are morphologically hilly and prone to disasters although at a minimum scale. Results of this study also show that many of the inhabitants of the residential expansion areas are of low education level and working as industrial labourers and construction workers. The others engage in trade and service activities. Some of them are also temporary residents.

The other districts, especially Gayamsari and Semarang Timur, are also exposed to residential development with the availability of non-built-up land and relatively flat topography. However, the growth and development of residential areas was not as massive as in the case of Gajah Mungkur and Candisari. It may be affected by the higher land prices compared to those in other districts.

Figure 8 shows the directions of residential development in Semarang city centre area, Indonesia.

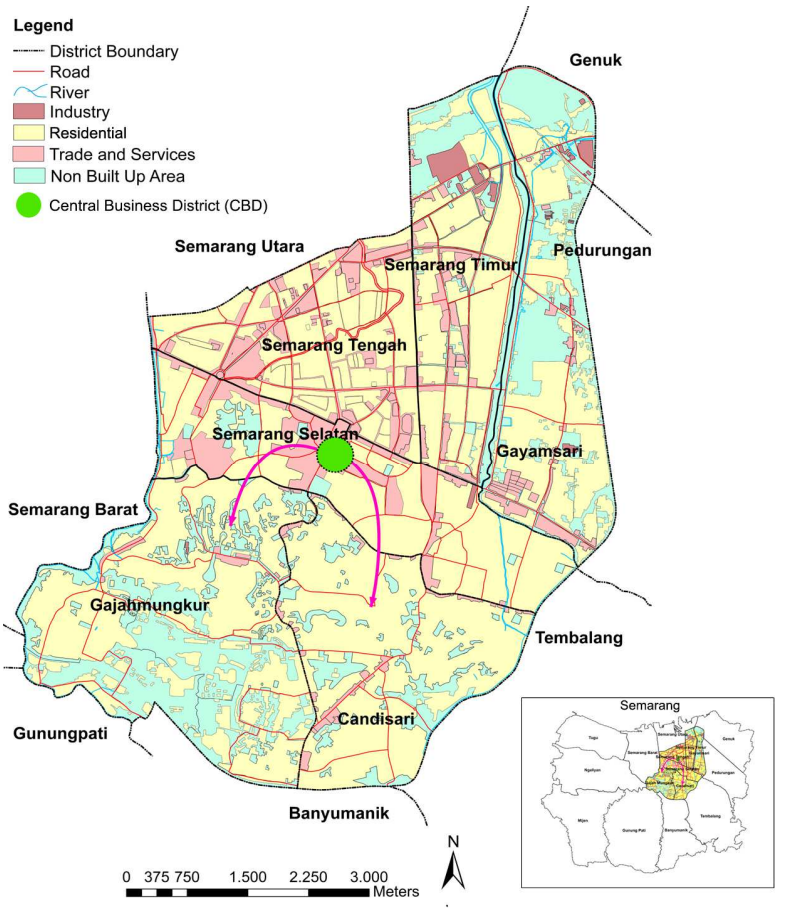

Fig. 8. Directions of residential development.

Another interesting aspect is that there has been no expansion of residential areas in Semarang Selatan District. It is perhaps due to the condition of non-built-up land in this district that is mostly used as green open spaces in the forms of city parks and other public facilities. This condition limits the chances of developing residential areas.

There is a particular type of relationship between the expansion of the residential area and the distance from the $\mathrm{CBD}$ that is affected by the availability of land and the location of facilities. Research results show that the non-built-up area for residential development is still available in all the districts. However, the trend in the period 2006-2016 delivers an essential lesson; that is, future residential expansion may go further and exploit even the 
unsuitable land. Therefore, the policy of limiting the growth of residential areas should be enforced more strictly to coordinate development to comply with the city spatial plan.

\section{ACKNOWLEDGEMENTS}

This research was funded by the Directorate of Research and Community Services of the Directorate General of Strengthening Research and Development at the Ministry of Research, Technology and Higher Education, the Republic of Indonesia.

The authors are grateful for that. The authors would also like to thank all staff in the six District Offices, BPS and Bappeda (Regional Development Planning Board) of Semarang City for providing data and information needed. Gratitude is also conveyed to the Department of Urban and Regional Planning of Diponegoro University for facilitating the authors to conduct the research.

\section{REFERENCES}

Ahmed Y. A. (2009), Settlements pattern and functional distribution in an emerging communities: a case of a local government area of Kwara State, Nigeria. The Social Sciences, 4(3), 256-263. Retrieved from: http://medwelljournals.com/abstract/?doi=sscience.20 09.256 .263

Akintunde J. A., Adzandeh E. A., Fabiyi O. O. (2016), Spatio-temporal pattern of urban growth in Jos Metropolis, Nigeria. Remote Sensing Applications: Society and Environment, 4, 44-54. DOI: https://doi.org/10.1016/j.rsase.2016.04.003

Aprillia Y., Pigawati B. (2018), Urban Sprawl Typology in Semarang City. Forum Geografi, 32(2). DOI: https://doi.org/10.23917/forgeo.v32i2.6369

Bagheri B., Tousi S. N. (2017), An explanation of urban sprawl phenomenon in Shiraz Metropolitan Area (SMA). Cities, (September), 1-20. DOI: https://doi.org/10.1016/j.cities.2017.10.011

Bhatt B., Gupta A. K., Gogoi G. (2006), Application of Remote Sensing and GIS for Detecting Land Use Changes : A Case Study of Vadodara, GIS Development. Retrieved from https://www.geospatialworld.net/ article/application-of-remote-sensing-and-gis-fordetecting-land-use-changes-a-case-study-of-vadodara/

Bourne L. S. (1982), Internal Structure of the City. New York: Oxford University Press.

Buchori I., Sugiri A. (2016), An empirical examination of sustainable metropolitan development in Semarang City, Indonesia. Australian Planner, 53(3), 163-177. DOI: https://doi.org/10.1080/07293682. 2016.1151905

Buchori I., Sugiri A., Hadi S. P., Wadley D., Liu Y. (2015), Developing a geographic information systembased assessment model for sustainable metropolitan development: The case of the Semarang metropolitan region, Indonesia. American Journal of Environmental Sciences, 11(2), 62. DOI: 10.3844/ajessp.2015.62.75

Buchori I., Sugiri A., Maryono M., Pramitasari A., Pamungkas I. T. D. (2017), Theorizing spatial dynamics of metropolitan regions: A preliminary study in Java and Madura Islands, Indonesia. Sustainable Cities and Society. DOI: https://doi.org/10.1016/j.scs. 2017.08.022

Budihardjo E. (1991), Arsitektur dan Kota di Indonesia. Bandung: Alumni.

Burgess E. W., McKenzie R. D., Wirth L. (1925), The city. University of Chicago Press.

Cats O., Zhang C., Nissan A. (2016), Survey methodology for measuring parking occupancy: Impacts of an on-street parking pricing scheme in an urban center. Transport Policy, 47, 55-63. DOI: https://doi.org/10.1016/j.tranpol.2015.12.008

Central Bureau of Statistics (2018), Kota Semarang Dalam Angka Tahun 2018 [Semarang in Figures. Year 2018]. Semarang.

Chadwick K. A., Collins P. A. (2015), Examining the relationship between social support availability, urban center size, and self-perceived mental health of recent immigrants to Canada: A mixed-methods analysis. Social Science and Medicine, 128, 220-230. DOI: https://doi.org/10.1016/j.socscimed.2015.01.036

Cheng J., Masser I. (2003), Urban growth pattern modeling: a case study of Wuhan city, P.R. China. Landscape and Urban Planning, 62(4), 199-217. DOI: https://doi.org/10.1016/So169-2046(02)00150-o

Christiaensen L., Todo Y. (2013), Poverty Reduction during the Rural-Urban Transformation The Role of the Missing Middle. The World Bank. DOI: https://doi.org/10.1596/1813-9450-6445

Clarke J. I. (1985), Patterns of settlement and factors affecting population distribution. London.

Daldjoeni (1987), Geografi Kota dan Desa. Bandung: Alumni.

Ding C. (2009), Policy and planning challenges to promote efficient urban spatial development during the emerging rapid transformation in China. Sustainability, 1(3), 384-408. DOI: https://doi.org/10.339o/su1030384

Donaghy M. M. (2013), Civil Society and Participatory Governance. Routledge. DOI: https://doi. org/10.4324/9780203098011

Ferreira J. A., Condessa B. (2012), Landscape and Urban Planning Defining expansion areas in small urban settlements - An application to the municipality of Tomar (Portugal). Landscape and Urban Planning, 107(3), 283-292. DOI: https://doi.org/10.1016/ j.landurbplan.2012.06.008

Festus Ibimilua Adewale, Amos I. O. (2015), Housing Policy in Nigeria: An Overview. American International Journal of Contemporary Research, 5(2), 53-59. Retrieved from www.aijcrnet.com/journals/ Vol_5_No_2_April_2015/8.pdf 
Glaeser E. L., Kallal H. D., Scheinkman J. A., Shleifer A. (1992), Growth in Cities. Journal of Political Economy, 100(6), 1126-1152.

Golledge R. G., Stimson R. (1987), Analytical Behavioral Geography. Routledge.

Government of Ireland (2009), Guidelines for Planning Authorities on Sustainable Residential Development in Urban Areas.

Government of the City of Semarang (2011), Semarang City Spatial Plan for 2011-2031 (Regional Regulation No. 14 of 2011). Semarang. Retrieved from: http://perpustakaan.bappenas.go.id/lontar/opac/them es/bappenas4/templateDetail.jsp?id=14216oandlokasi =lokal

Granath Hansson A. (2017), Promoting planning for housing development: What can Sweden learn from Germany? Land Use Policy, 64, 470-478. DOI: https://doi.org/10.1016/j.landusepol.2017.03.012

Hagget P. (1985), Geography: A Modern Synthesis. London: Harper and Row Publisher.

Handayani W., Rudiarto I. (2014), Dynamics of Urban Growth in Semarang Metropolitan - Central Java: An Examination Based on Built-Up Area and Population Change. Journal of Geography and Geology, 6(4), 80-87. DOI: https://doi.org/10.5539/jgg.v6n4 p8o

Harris C. D., Ullman E. L. (1945), The Nature of Cities. The ANNALS of the American Academy of Political and Social Science, 242(1), 7-17. DOI: https://doi.org/10.1177/o00271624524200103

Hudson F. S. (1974), Geography of Settlements. London: Mac Donald and Evans.

Keivani R., Werna E. (2001), Modes of housing provision in developing countries. Progress in Planning, 55(2), 65-118. DOI: https://doi.org/10.1016/So3059006(00)00022-2

Lal K., Kumar D., Kumar A. (2017), Spatiotemporal landscape modeling of urban growth patterns in Dhanbad Urban Agglomeration, India using geoinformatics techniques. Egyptian Journal of Remote Sensing and Space Science, 20(1), 91-102. DOI: https://doi.org/10.1016/j.ejrs.2017.01.003

Mahavir D. B. (1996), Modelling settlement patterns for metropolitan regions: inputs from remote sensing. ITC, Enschede, The Netherlands.

Marble M., Dadhich P. N., Hanaoka S. (2012), Remote Sensing Application in Monitoring Impact of Mining Activities on Urban Growth.

Maza A., Villaverde J., Hierro M. (2013), Explaining the settlement patterns of foreigners in Spain. Applied Geography, 40, 11-20. DOI: https://doi. org/10.1016/j.apgeog.2013.01.004

McGill R. (1998), Urban management in developing countries. Cities, 15(6), 463-471. DOI: https://doi.org/ 10.1016/So264-2751(98)ooo41-9

Mockrin M. H., Reed S. E., Pejchar L., Jessica S. (2017), Balancing housing growth and land conservation: Conservation development preserves private lands near protected areas. Landscape and Urban Planning, 157, 598-607. DOI: https://doi.org/ 10.1016/j.landurbplan.2016.09.015

Olajoke A. (2017), The Pattern, Direction and Factors Responsible for Urban Growth in a Developing African City : A Case Study of Ogbomoso The Pattern, Direction and Factors Responsible for Urban Growth in a Developing African City: A Case Study of Ogbomoso, 9274, 221-226. DOI: https://doi.org/10.1080/0970 9274.2007.11906025

Oruç S. Z. (2013), Harbor Settlement Patterns of the Second Millennium BC in Cilicia and the Amuq.

Pacione M. (1984), Rural Geography. London: Harper and Row Publisher.

Patino J. E., Duque J. C. (2013), A review of regional science applications of satellite remote sensing in urban settings. Computers, Environment and Urban Systems, 37(1), 1-17. DOI: https://doi.org/10.1016/j.compenvur bsys.2012.06.003

Pigawati B., Rudiarto I. (2011), Penggunaan Citra Satelit Untuk Kajian Perkembangan Kawasan Permukiman Di Kota Semarang, 25(2), 140-151.

Pigawati B., Yuliastuti N., Mardiansjah F. H. (2017), Pembatasan Perkembangan Permukiman Kawasan Pinggiran Sebagai Upaya Pengendalian Perkembangan Kota Semarang. Tataloka, 19(4), 306. DOI: https://doi.org/10.14710/tataloka.19.4.306-319

Pigawati B., Yuliastuti N., Mardiansjah F. H. (2018), The Settlements Growth in Mijen District, Suburb of Semarang. In IOP Conference Series: Earth and Environmental Science (Vol. 123). DOI: https://doi.org/10.1088/1755-1315/123/1/012034

Porter D. R. (2012), Managing growth in America's communities. Island Press.

Rapoport A. (1969), House Form and Culture. Englewood Cliffs: Prentice Hall.

Richardson H. (1993), Problems of metropolitan management in Asia. Urban Management: Policies and Innovations in Developing Countries, 51-75.

Rodríguez-Pose A., Hardy D. (2015), Addressing poverty and inequality in the rural economy from a global perspective. Applied Geography, 61, 11-23. DOI: https://doi.org/10.1016/j.apgeog.2015.02.005

Sahana M., Hong H., Sajjad H. (2018), Analyzing urban spatial patterns and trend of urban growth using urban sprawl matrix: A study on Kolkata urban agglomeration, India. Science of the Total Environment, 628-629, 1557-1566. DOI: https://doi.org/10.1016/ j.scitotenv.2018.02.170

Sarkar A. (2010), Analysis of Human Settlement Patterns Using RS and GIS in the Plains of West Bengal. The On-Line Indian Journal of Spatial Science, I (1).

Seto K. C., Fragkias M., Güneralp B., Reilly M. K. (2011), A Meta-Analysis of Global Urban Land Expansion. PLoS ONE, 6(8), e23777. DOI: https://doi.org/10.1371/journal.pone.0023777 
Simich L., Beiser M., Stewart M., Mwakarimba E. (2005), Providing Social Support for Immigrants and Refugees in Canada: Challenges and Directions. Journal of Immigrant and Minority Health, 7(4), 259268. DOI: https://doi.org/10.1007/s10903-005-5123-1 Sumaatmadja N. (1989), Studi Lingkungan Hidup. Bandung: Alumni.

Wang M., Krstikj A., Koura H. (2017), Effects of urban planning on urban expansion control in Yinchuan City, Western China. Habitat International, 64, 85-97. DOI: https://doi.org/10.1016/j.habitatint. 2017.04.008

Weng Q. (2010), Remote Sensing and GIS Integration: Theories, Methods, and Applications. New York: McGraw-Hill Company.

Werna E. (1998), Urban management, the provision of public services and intra-urban differentials in Nairobi. Habitat International, 22(1), 15-26. DOI: https://doi. org/10.1016/So197-3975(97)00019-2

Whynne-Hammond C. (1985), Elements of Human Geography. Retrieved from https://books.google.co.id/ books?id=sWZ-AAAAMAAJ

Wulangsari A. (2014), Tipologi Segregasi Permukiman berdasarkan Faktor dan Pola Permukiman di Solo Baru, Sukoharjo. JURNAL PEMBANGUNAN WILAYAH and KOTA, 10(4), 387. DOI: https://doi.org/10.14710/pwk.v10i4.8166
Xu Y., Zhang X. (2017), The residential resettlement in suburbs of Chinese cities : A case study of Changsha. Cities, 69(June), 46-55. DOI: https://doi.org/10.1016/ j.cities.2017.06.002

Yang R., Xu Q., Long H. (2016), Spatial distribution characteristics and optimized reconstruction analysis of China's rural settlements during the process of rapid urbanization. Journal of Rural Studies, 47, 413-424. DOI: https://doi.org/10.1016/j.jrurstud.2016.05.013

Yeh A. G.-O. (1999), Urban Spatial Structure in a Transitional Economy. Journal of the American Planning Association, 65(4), 377-394. DOI: https://doi. org/10.1080/01944369908976069

You H., Yang X. (2017), Urban expansion in 30 megacities of China: categorizing the driving force profiles to inform the urbanization policy. Land Use Policy, 68, 531-551. DOI: https://doi.org/10.1016/ j.landusepol.2017.06.020

Zee D. Van Der (1979), Human Geography of Rural Settlement and Population. Enschede. 